\title{
Pendampingan Peroleh Legalitas Usaha Mikro Di Desa Puger Wetan Kecamatan Puger Kabupaten Jember
}

\author{
Emy Kholifah R., Suwignyo Widagdo, Akbar Maulana \\ Universitas Muhammadiyah Jember \\ e-mail: emykholifah@unmuhjember.co.id, suwignyo@stie-mandala.ac.id, \\ akbar.maulana@unmuhjember.ac.id
}

Diterima: April 2021 | Dipublikasikan: Juni 2021

\begin{abstract}
ABSTRAK
Usaha mikro, bagi perempuan adalah sektor kerja yang sangat menunjang alokasi ketenaga kerja perempuan. Hampir delapan puluh persen tenaga kerja perempuan kelompok bawah terserap dalam sektor kerja mandiri yakni usaha mikro. Jenis usaha mikro yang beragam dan tidak bergantung pada tingkat keterampilan kerja yang tinggi menjadikan perempuan teralokasi pada bidang ini lebih besar dari pada usaha sektor lain. Namun demikian usaha mikro yang digeluti oleh perempuan bertahun-tahun dan memiliki prospek untuk berkembang terhambat oleh terbatasnya fasilitasi dari pihak pemerintah. Hal ini disebabkan usaha mikro minim memiliki persyaratan bagi sebuah usaha yang dianggap establish. Sejauh ini usaha mikro yang oleh karena sifatnya mudah berubah dan beralih bisnis (jenis usaha) maka pihak perbankan atau pihak pemerintah baik pihak dinas koperasi, usaha mikro dan menengah mengalami kekhawatiran dan kesulitan untuk memberikan fasilitas pengembangan usaha. Legalitas usaha dan konsistensi usaha dari usaha-usaha mikro ini yang merupakan salah satu indikator penting untuk akses fasilitas pengembangan usaha dari pihak perbankan dan pihak pemerintah. Pengabdian pada masyarakat kali ini berusaha untuk memberikan sosialisasi dan pendampingan bagi para pengusaha mikro perempuan pesisir di Desa Puger Wetan untuk memperoleh Legalitas usaha mikro dari pemerintah terkait.
\end{abstract}

Kata Kunci: usaha mikro perempuan pesisir, pemahaman, pendampingan peroleh legalitas usaha

\begin{abstract}
Micro enterprises, for women, are a work sector that greatly supports the allocation of women's workforce. Nearly eighty percent of the lower class female workforce is absorbed in the independent work sector, namely micro-enterprises. The types of micro businesses that are diverse and do not depend on a high level of work skills make women more allocated to this field than businesses in other sectors. However, micro businesses that have been engaged in by women for years and have the prospect of developing are hampered by limited facilitation from the government. This is because micro businesses have minimal requirements for a business that is considered to be established. So far, micro businesses, which are easy to change and change business (type of business), so the banking sector or the government, both from the cooperative agency, micro and medium enterprises, have experienced concerns and difficulties in providing business development facilities. Business legality and business consistency of these micro businesses are important indicators for access to business development facilities from the banking sector and the government. This time, community service is trying to provide socialization and assistance for coastal women micro entrepreneurs in Puger Wetan Village to obtain the legality of micro businesses from the relevant government.
\end{abstract}

Keywords: coastal women's micro business, understanding, assistance in obtaining business legality

\section{PENDAHULUAN}

Sektor UMKM telah terbukti mampu hidup dan berkembang dalam menghadapi badai krisis. Keberadaannya telah dapat memberikan kontribusi terhadap Produk Domestik Bruto (PDB) dalam penyerapan tenaga kerja dan peningkatan ekspor. Berdasarkan data Badan Produk Domestik Bruto (PDB) Pusat Statistik (BPS) pada 2009, jumlah UMKM di Indonesia sebanyak 520.220 unit, sedangkan jumlah koperasi sampai dengan pertengahan 2009 sebanyak 166.100 unit yang tersebar di seluruh Indonesia sangat potensial untuk dikembangkan. (www.suaramedia.com). Prospek bisnis UMKM dalam era perdagangan bebas dan otonomi 
daerah sangat tergantung pada upaya yang ditempuh oleh pemerintah dalam mengembangkan bisnis UMKM. Untuk mencapai iklim usaha yang kondusif ini, diperlukan penciptaan lingkungan kebijakan yang kondusif bagi UMKM. Kebijakan yang kondusif dimaksud dapat diartikan sebagai lingkungan kebijakan yang transparan dan tidak membebani UMKM secara finansial bicara berlebihan. Ini berarti berbagai campur tangan pemerintah yang berlebihan, baik pada tingkat pusat maupun daerah harus dihapuskan, khususnya penghapusan berbagai peraturan dan persyaratan administratif yang rumit dan menghambat kegiatan UKM. (Firdausy, 2000) Tetapi permasalahan utama yang dihadapi UMKM adalah kesulitan dalam mengakses kredit untuk modal usaha. Hal ini disebabkan karena pihak perbankan menganggap UMKM tidak layak untuk mendapatkan kredit, karena sektor UMKM sulit berkembang dan adanya kekhawatiran terjadinya kredit macet. Menurut Purwanto (2010), para pengusaha kecil menengah (UKM) mengalami kesulitan dalam mengakses kredit perbankan karena masih terjadi perbedaan perspektif antara sisi UKM dan sisi perbankan dalam pemberian kredit. Namun, tekanan yang dihadapi perbankan berupa semakin ketatnya persaingan dan semakin menipisnya keuntungan dari segmen korporasi (perusahaan besar), memaksa perbankan untuk masuk ke segmen UKM. Permasalahan utama yang dihadapi UMKM di Desa Puger Wetan adalah terkait dengan modal untuk pengembangan usaha. Umumnya pengelola UMKM kesulitan dalam mendapatkan akses kredit untuk modal usaha dari lembaga perbankan. Hal ini disebabkan karena pihak perbankan menganggap UKM tidak layak untuk mendapatkan kredit, karena sektor UMKM sulit berkembang dan adanya kekhawatiran terjadinya kredit macet. Oleh karena itu diperlukan pendidikan dan keterampilan dalam mengelola suatu usaha supaya bisa berkembang dengan baik. Tetapi realita yang ada di masyarakat, banyak perempuan dengan tingkat pendidikan rendah dan tidak mempunyai skill yang cukup baik dalam menjalankan usahanya sehingga usahanya banyak yang terpuruk. Dengan tingkat pendidikan yang rendah, perempuan sulit untuk mengakses kredit dari lembaga perbankan. Apalagi persyaratan yang diminta pihak bank kepada UMKM untuk mengajukan kredit sangat banyak termasuk harus adanya jaminan. Jaminan yang disyaratkan pihak bank seperti sertifikat tanah, rumah dan surat kepemilikan kendaraan (BPKB), umumnya diatasnamakan suami. Perempuan tidak mempunyai kontrol terhadap sumberdaya yang ada, seperti: tanah, rumah dan kendaraan. Akibatnya banyak UKM yang dikelola perempuan terjerat dalam hutang rentenir yang sangat memberatkan sehingga usahanya mengalami kebangkrutan. Meskipun pemerintah telah mengeluarkan program Kredit Usaha Rakyat (KUR) untuk membantu UMKM yang merupakan kredit lunak tanpa jaminan untuk skim kredit kurang dari Rp. 5.000.000,00 tetapi pada kenyataannya pihak bank selalu meminta jaminan supaya pihak UKM mempunyai motivasi dalam menyelesaikan kewajibannya.

\section{METODE PELAKSANAAN}

Metode pelaksanaan menjelaskan tahapan atau langkah-langkah dalam melaksanakan solusi yang ditawarkan untuk mengatasi permasalahan mitra. Pada bagian ini wajib mengisi uraian kepakaran dan tugas masing-masing anggota tim pengabdian kepada masyarakat dalam menyelesaikan persoalan atau kebutuhan mitra.

\section{Waktu dan Tempat}

Program ini dilakukan di Desa Puger Wetan Kecamatan Puger Kabupaten Jember. Program ini akan dilaksanakan pada bulan Desember 2020 sampai dengan bulan Maret 2021.

\section{Tahapan Pelaksanaan Kegiatan}

Tahap Persiapan melaksanakan koordinasi dengan mitra, mengidentifikasi permasalahan mitra, menyusun modul, sosialisasi kepada masyarakat, mengadakan koordinasi dengan OPD atau instansi lainnya terkait.

Tahap Pelaksanaan, meliputi kegiatan koordinasi dan komunikasi secara aktif kepada desa mitra dan lembaga lainnya, pelaksanaan pelatihan proses dan tahapan penyusunan dokumen legalitas, simulasi kegiatan penyusunan usaha mikro, pembuatan dokumentasi kegiatan. 
Tahap Evaluasi, penyusunan laporan kegiatan, pembuatan laporan, publikasi kegiatan, pembuatan artikel.

Adapun rencana kegiatan, PKM akan dilaksanakan selama 3-6 bulan yang meliputi tahap persiapan pendampingan dan pembuatan dokumen legalitas usaha mikro (melaksanakan koordinasi dengan mitra, mengidentifikasi permasalahan mitra, menyusun modul, sosialisasi kepada peserta, mengadakan koordinasi dengan OPD dan instansi terkait), pelaksanaan pendampingan (kegiatan koordinasi dan komunikasi desa mitra, pelatihan penyusunan dokumen, simulasi kegiatan, pembuatan dokumentasi kegiatan), penyusunan laporan kegiatan (pembuatan laporan, publikasi kegiatan, pembuatan artikel). Adapun mitra PKM dalam pengabdian ini adalah Kelompok Nelayan "Salsabil" Desa Puger Wetan Kecamatan Puger Kabupaten Jember yang dipilih sebagai mitra karena kelompok tersebut berada di lingkungan yang unik dengan berbagai macam kondisi permasalahan yang ada, baik itu dari segi ekonomi kreatif berbasis potensi pangan lokal, agama dan budaya serta kelompok mitra juga memiliki lokasi yang representative dan strategis.

\section{HASIL DAN PEMBAHASAN}

Pada Hari Sabtu tanggal 27 Februari 2021 bertempat di Warung Sego Pedes Lestari Kecamatan Puger dilaksanakan kegiatan pendampingan peroleh legalitas usaha mikro. Dalam acara tersebut turut hadir Dr. Emy Kholifah R., M.Si selaku Ketua Pengabdian dan Dr. Dr. Suwignyo Widagdo, SE, MM selaku Anggota 1 yang bertindak sebagai pembicara inti. Turut hadir pula Akbar Maulana, S.IP., M.Si selaku Anggota 2 berperan sebagai moderator dalam acara tersebut.

Inti acara ini adalah pendampingan terhadap pelaku usaha mikro kecil dan menengah (UMKM) yang pada realitanya ternyata banyak yang tidak mempunyai legalitas hukum yang berlaku. Pelaku usaha mikro kecil dan menengah (UMKM) dalam rutinitas sehari-hari kerap kali mengalami dan memperoleh tantangan yang cukup besar di masyarakat. Baik dalam sisi penerimaan masyarakat maupun urusan legalitas dari usaha tersebut. Oleh karenanya, dalam kegiatan ini dipaparkan secara tuntas tentang pentingnya legalitas dan tahapan yang perlu ditempuh oleh UMKM untuk mendapatkan legalitas termasuk dampak perekonomian yang akan didapatkan oleh pelaku usaha. Selain sosialiasi tentang perolehan legalitas dan izin ysaha, dilakukan juga pengumpulan persyaratan guna pengurusan legalitas dan ijin usaha kepada lembaga terkait.

Metode pelaksanaan pengabdian ini dilakukan agak berbeda dari rencana awal, dengan sedikit penyesuaian dikarenakan adanya pandemi Covid 19. Pada awalnya, seluruh pelaku usaha yang diundang pada kegiatan ini kami hadirkan dalam satu hari jadwal kegiatan di salah satu tempat yaitu di Warung Sego Pedes Lestari Kecamatan Puger. Akan ketapi karena masih dalam musim pandemi Covid 19, kegiatan tersebut kami dipecah menjadi 2 kali sesi dengan menetapkan protokol kesehatan yang ketat sesuai standar yang ditetapkan oleh lembaga dan pemerintah. Kami melaksanakan pengabdian membagi dua sesi. Sesi pertama, dengan dipandu oleh moderator acara kami mengadakan kegiatan dengan materi terkait dengan bagaimana untuk memperoleh legalitas usaha serta sarat-sarat apa saja yang diperlukan, juga terkait dengan bagaimana manfaat dan kegunaan setelah pelaku usaha tersebut memeroleh legalitas secara sah dari pemerintah yang diperkuat dengan sesi diskusi terkait permasalahan-permasalahan yang dimiliki oleh pelaku usaha. Kemudian di sesi kedua dengan dipandu oleh moderator juga diisi dengan materi terkait dengan apa saja manfaat keuntungan dari segi ekonomi dan bagaimana strategi dalam memperluas pasar penjualan terhadap produk-produk pelaku usaha setelah mendapatkan legalitas usaha dari Dinas Koperasi dan Usaha Mikro Kecil dan Menengah di Desa Puger Wetan Kecamatan Puger Kabupaten Jember. Selain itu juga dibantu oleh anggota pengabdian yakni para mahasiswa juga mengajarkan bagaimana strategi atau cara membuat dan membangun digital marketing, mulai dari membuat konten, sampai pada membranding produk agar memperoleh daya jual yang cukup tinggi kepada para pembeli produk yang juga langsung 
dipraktekkan menggunakan smartphone masing-masing para pelaku usaha sekaligus diskusi secara intensif.

Melalui kegiatan pegabdian kepada masyarakat ini, kami terus berusaha memacu sinergi dan kolaborasi dari masyarakat khususnya UMKM agar bisa memberikan sumbangsih dan memperoleh legalitas yang valid dan sah diakui oleh negara melalui Pengembangan Industri Ekonomi Kreatif Desa Berbasis Kearifan Lokal Dan Kewirausahaan yang terpadu, sinergis dan bermanfaat bagi pelaku usaha mikro di daerah Puger Wetan Kecamatan Puger Kabupaten Jember.

\section{Tahap Pelaksanaan Kegiatan Pengabdian}

\section{a. Tahap Persiapan :}

Beberapa tahapan persiapan sebelum melaksanakan kegiatan pengabdian dipersiapkan secara continue oleh Bapak Akbar Maulana yang dibantu oleh mahasiswa. Pada tahap awal para angggota pelaksana mempersiapkan pedoman dokumen proposal, persiapan tempat kegiatan dan juga menghimpun para peserta pendampingan pelaku usaha sebanyak 11 orang di Desa Puger Wetan. Beberapa keperluat surat menyurat, seperti surat undangan pelaku usaha, surat peminjaman tempat dan operasional lainnya direncanakan pada hari Rabu tanggal 24 Februari 2021. Selanjutnya tim anggota yang dipimpin oleh Bapak Akbar Maulana melaksanakan koordinasi secara intensif dengan mitra, mengidentifikasi permasalahan mitra, menyusun desain konsem pendampingan pelaku usaha mikro dan merancang pembuatan panduan modul pendampingan. Sosialisasi dan koordinasi dengan mitra dan peserta pelaku usaha awalnya dilakukan melalui dokumen surat dengan menggunakan pesan singkat whatsapp untuk mempermudah komunikasi antara tim pengabdian dengan mitra dikarenakan lokasi pengabdian lumayan cukup jauh. Disamping itu, salah satu mahasiswa juga bertempat tinggal di lokasi pengabdian sehingga dapat mempermudah dan melancarkan koordinasi dan komunikasi dengan mitra di Desa Puger Wetan Kecamata Puger. Tempat pelaksanaan mengalami perubahan desain dan jadwal kegiatan, yang semula direncanakan pendampingan di Kantor Desa Puger Wetan, bergeser di Rumah Makan Sego Bebek Puger yang tak jauh dari Kantor Desa Puger Wetan, hal ini karena pihak pemerintah desa masih membatasi aktivitas kegiatan di pendopo desa dikarenakan masih dalam musim pandemi Covid 19. Adapun tanggal pelaksanaan kegiatan yang awalnya pada hari Jumat tanggal 26 Februari 2021 dirubah pada hari Sabtu tanggal 27 Feveruari 2021.

\section{b. Tahap Pelaksanaan :}

Pelaksanaan kegiatan pengabdian ini dilaksanakan pada tanggal 27 Februari 2021. Kami mengadakan kegiatan pengabdian di tempat Rumah Makan Sego Bebek Kecamatan Puger dengan mengumpulkan mitra dan berbagai macam peserta pelaku usaha mikro di Desa Puger Wetan. Pada pelaksanaan pengabdian ini di sesi pertama dimulai dengan pemberian materi oleh Ibu Dr. Emy Kholifah R., M.Si yang berkaitan dengan peroleh legalitas pelaku usaha mikro termasuk dengan syarat-syarat apa saja yang diperlukan untuk mendapatkan izin usaha dari pihak pemerintah. Para pelaku usaha mikro antusias dengan materi yang diberikan oleh Ibu Emy Kholifah. Terlihat bahwa para pelaku usaha tersebut banyak memberikan pertanyaan seputar kepengurusan izin usaha, dikarenakan hampir semuanya sampai saat ini tidak memiliki surat keterangan usaha dari pihak Dinas Koperasi dan Usaha Mikro Kecil dan Menengah. Menurut mereka, ada secercah harapan baru bagi para elaku usaha mikro kecil dan menengah ini ketika kami mensosialisasikan kebijakan untuk mempermudah kepengurusan legalitas izin usaha.

Pada sesi kedua, dan ditempat yang sama juga dilanjutkan oleh Bapak Dr. Suwignyo Widagdo, SE., MM. Dengan memberikan dan menyampaikan materi yang terkait dengan dampak penghasilan ekonomi yang dihasilkan jika para pelaku usaha memiliku surat keterangan usaha secara legal dari pemerintah. Pembicara juga menyampaikan dalam materi bahwa jika semua para pelaku usaha di Puger Wetan ini mendapatkan surat keterangan usaha dari Dinas Koperasi dan Usaha Mikro Kecil dan Menengah, maka para pelaku usaha mikro juga bisa mendapatkan kemudahan dalam akses pembiayaan ke lembaga keuangan bank dan non-bank. Selain itu, surat keterangan usaha juga bisa digunakan pula oleh para pelaku usaha mikro untuk 
dapat lebih mudah mengakses ke sumber-sumber daya produktif lainnya, seperti akses pemanfaatan teknlogi, pasar, dan pelatihan sumber daya manusia bagi para pelaku usaha mikro. Hal ini tentu dapat meningkatkan produktifita pelaku usaha mikro untuk mengembangkan usahanya baik dari segi pembiyaan modal dan kompetensi para pelaku usah mikro di Desa Puger Wetan. Penyampaian informasi materi ini tentu dapat memicu semangat bagi para pelaku usaha mikro untuk mendapatkan dan memperoleh surat keterangan usaha untuk memberikan dampak ekonomi dan legalitas bagi usahanya secara mandiri dan berkelanjutan. Tentunya melalui sinergi kolaborasi dari berbagai pihak utamanya Pemerintah Desa Puger Wetan Kecamatan Puger di Kabupaten Jember.

\section{c. Pendampingan dan Jemput Bola Program Pengabdian}

Sebaik apapun suatu program bila tanpa fungsi pendampingan, tingkat keberhasilannya sering kali stagnan. Oleh karena itu, kami melalui Program Studi Ilmu Pemerintahan FISIP UM Jember dengan mengimplementasikan Catur Dharma Perguruan Tinggi yang salah satunya adalah Pengabdian Kepada Masyarakat melakukan fungsi pendampingan yang melekat di dalamnya. Sesuai dengan Surat Edaran Nomor 15/M.KUKM/I/2015 tanggal 22 Januari 2015, pendampingan pelaku usaha mikro akan difasilitasi oleh Kementerian Koperasi dan UKM yang mana pada pelaksanaan di daerah akan di backup oleh Dinas Koperasi dan UMKM Kabupaten Jember. Selain itu, dalam surat edaran tersebut dikatakan bahwa Gubernur, Bupati, Walikota dan Kepala Desa agar membantu para pendamping pelaku usaha mikro dalam melaksanakan peran pendampingan sehingga optimal pelayanan kepada pelauk usaha mikro. Adapun tugas pendamping ini, kata Braman, adalah untuk membantu pelaku usaha mikro dalam melengkapi dan menyerahkan berkas pendaftaran ke Kecamatan dan Kelurahan, memverifikasi berkas dokumen yang dibutuhkan, hingga memberikan bimbingan pasca perolehan surat keterangan usaha seperti akses ke pembiayaan. Oleh karena itu, dengan mengacu dan berdasarkan surat edaran tersebut kami sebagai akademisi bermaksud ingin menjemput bola dan membantu pemerintah daerah untuk memfasilitasi pelaku usaha mikro dalam mendapatkan legalitas usaha dari Dinas Koperasi dan UMKM Kabupaten Jember. Peran akademisi melalui perguruan tinggi sekaligus memberikan dampak nyata dalam kesejahteraan masyarakat dalam peningkatan perekonomian bangsa.

\section{d. Jemput Bola}

Sementara itu Tim Pengabdian ingin segera mengimplementasikan perolehan legalitas usaha mikro bagi pelaku usaha yang berada pada level desa, dalam hal ini Desa Puger Wetan Kecamatan Puger. Oleh karena itu, pendampingan yang kami lakukan mendorong bentuk nyata hingga ke level desa dengan strategi jemput bola dengan menggunakan prinsip cepat dan mudah. Sumberdaya yang kami miliki juga sangat mumpuni disampiang sebagai akademisi, tim juga terdiri dari beberapa mahasiswa yang pada akhirnya mereka akan terjun langsung kepada masyarakat. Merasakan bagaimana teori bisa diimplementasikan dan apa saja hambatanhambatan yang akan diselesaikan nantinya. Hal ini tentu memberikan pengalaman dalam proses pengabdian kepada masyarakat bagi mahasiswa. Program pendampingan ini juga didukung oleh pendanaan internal dari Perguruan Tinggi Muhammadiyah dalam hal ini Universitas Muhammadiyah Jember untuk mendukung serta mendampingi pelaku usaha mikro dan kecil memperoleh surat keterangan usaha dari Dinas Koperasi dan Usaha Mikro Kecil dan Menengak Kabupaten Jember. Dengan demikian, kami berharap melalui Surat Keterangan Usaha (SKU) ini para pelaku usaha di Desa Puger Wetan diiharapkan bisa mendapatkan kemudahan dalam akses pembiayaan ke lembaga keuangan bank dan non-bank.

Kehadiran program pengabdian masyarakat yang dilaksanakan oleh dosen dan mahasiswa Program Studi Ilmu Pemerintahan FISIP UM Jember ini diharapkan dapat menjadi solusi bagi pelaku usaha mikro kecil yang sering kali terkendala dengan legalitas ijin udahanya dan minimnya modal dikarenakan mengalami kesulitan untuk memperoleh akses pembiayaan dari bank. Melalui dukungan ini juga ke depan diharapkan pelaku usaha mikro di Desa Puger Wetan Kecamatan Puger bisa memberdayakan sektor usaha mikro kecil hingga memiliki daya saing tinggi agar dapat bertahan menghadapi persaingan global. 


\section{KESIMPULAN DAN SARAN}

Pendampingan ini dapat membuat produk UMKM memiliki branding yang otentik sehingga bisa membawa usaha cepat dikenal dan mudah berkembang secara luas. Dengan branding yang kuat, identitas bisnis yang diciptakan pun semakin baik serta dengan adanya pendampingan ini UMKM yang terdata sebanyak 210 UMKM tercatat baru 13 UMKM yang memiliki legalitas produk dan sudah kami . Masih perlu sosialisasi dan pendampingan untuk legalitas, karena belum semua pelaku UKM di Desa Kenongo memahami pentingnya legalitas baik produk maupun usahanya, terlebih masih menganggap mahal biaya legalitas. Padahal jika telah memiliki legalitas, maka peluang untuk mengembangkan usahanya jadi lebih luas.Dari 210 anggota pelaku UKM Desa Kenongo baru 13 yang telah memiliki legalitas.

\section{Kesimpulan}

\section{KESIMPULAN DAN SARAN}

Berdasarkan hasil pembahasan diatas, maka dapat disimpulkan sebagai berikut :

1. Pelaksanaan Pengabdian Kepada Masyarakat dengan tema Peroleh Legalitas Usaha Mikro Kecil dan Menengah di Desa Puger Etan Kecamatan Puger sudah berjalan dengan baik, hal ini dapat terlihat dari antusiasnya para pelaku usaha mikro pada saat proses pendampingan dan para pelaku usaha mikro tersebut sudah mendapatkan Surat Keterangan Usaha (SKU) dari Dinas Koperasi dan UMKM Kabupaten Jember.

2. Pada tataran kebijakan atau regulasi yang telah dibuat oleh pemerintah diharapkan dapat memberikan kemudahan bagi pelaku usaha mikro dalam kepengurusan segela bentuk usaha yang rintis oleh masyarakat.

3. Perlu dilakukan pemetaan produk unggulan UMKM dan pendampingan terhadap kepengurusan izin legalitas usaha bagi pelaku usaha mikro sampai kepada pemasaran produk yang dihasilkan dengan menerapkan sistem pemasaran secara teknologi.

4. Pentingnya memiliki izin usaha mikro bagi pelaku usaha di Desa Puger Wetan saat ini. Dengan memiliki Surat Keterangan Usaha (SKU) maka dijamin usaha para pelaku mikro kedepannya menjadi semakin maju dan bisa berkembang serta dapat bersaing dengan pasar global.

\section{Saran}

Berdasarkan kesimpulan diatas, maka penulis dapat memberikan saran sebagai berikut :

1. Bagi pelaku usaha mikro perlu aktif untuk bekerjasama dan berkoordinasi dengan pemerintah desa atau pemerintah daerah untuk mensukseskan usaha mikronya. Keaktifan pelaku usaha mikro merupakan penentu kesiapan atau tidaknya bersaing dalam pasar bebas saat ini.

2. Mengingat bahwa keberadaan program pendampingan peroleh legalitas usaha mikro di Desa Puger Wetan adalah untuk kemajuan pembangunan perekonomian di desa, maka diharapkan para pelaku usaha mikro harus memiliki izin secara legal. Bukan hanya usaha yang skala besar tapi juga usaha skala kecil juga harus memiliki.

3. Untuk menunjang terlaksananya legalitas usaha mikro yang baik, diharapkan juga peran serta dari Tim Pendamping tingkat Kecamatan atau Desa untuk dapat membantu masyarakatnya dalam mengurus izin legalitas usaha mikro kecil agar bisa membawa dampak perubahan sosial ekonomi yang baik bagi masyarakat terutama di Desa Puger Wetan Kecamatan Puger.

\section{UPCAPAN TERIMAKASIH}

Ucapan terima kasih disampaikn kepada semua pihak yang telah berperan dalam Program Pengabdian Peroleh Legalitas Usaha Mikro di Desa Puger Wetan Kecamatan 
Puger Kabupaten Jember. Terutama kepada mitra kami Kelompok Nelayan Salsabil dan Dinas Koperasi dan UMKM Kab. Jember. Sehingga legalitas usaha bagi pelaku mikro di Desa Puger Wetan ini dapat dipergunakan sebagaimana mestinya dan dituangkan dalam bentuk tulisan dan diinformasikan kepada pelaku usaha di seluruh wilayah Kabupaten Jember

\section{DAFTAR PUSTAKA}

Andriani, Soemantri. (2003). Tanggung Renteng Setia Budi Wanita, Semarang: Limpad.

BAPPEKO. (2008). Badan Perencanaan Pembangunan Kota Malang.

Carunia Mulya Firdausy dan Rani Idawati. (2017). Effects of Media Promotion on Customers Purchase Decision Process of insurance companies in Albania, International Journal of Management Science and Business Administration, Vol 3, No 2, Hal $42-49$

Hubeis, Musa. 2009. Prospek Usaha Kecil dalam wadah Inkubator Bisnis, Ghalia Indonesia, Jakarta.

Hadiyati, E. (2009). Kajian Pendekatan Pemasaran Kewirausahaan dan Kinerja Penjualan Usaha Kecil. Jurnal Manajemen Dan Kewirausahaan (Journal of Management and Entrepreneurship), 11(2), 183-192. https://doi.org/10.9744/jmk.11.2.pp.183-192

Huda, N. dan H. M. (2010). Lembaga Keuangan Islam Tinjauan Teoritis dan Praktis. Prenada Media Group.

Priminingtyas, D. (2010). Peran Perempuan Dalam Pengembangan Sektor Usaha Mikro Kecil Menengah (UMKM). 1-7.http://dinanovia.lecture.ub.ac.id/files/2013/10/Paper-LoknasGender-UKM.pdf

Lembaga Penelitian dan Pengabdian Masyarakat. (2019). Panduan Pengabdian Internal Edisi II. Universitas Muhammadiyah Jember.

Purwanto. (2010). Evaluasi Hasil Belajar. Yogyakarta: Pustaka Pelajar.

Peraturan Pemerintah Nomor 98 Tahun 2014 tantang Perizinan Untuk Usaha Mikro Kecil dan Menengah

Peraturan Menteri Dalam Negeri RI Nomor 114 Tahun 2014 tentang Pedoman Pembangunan Desa.

Peraturan Menteri Koperasi Dan Usaha Kecil Menengah Republik Indonesia Nomor 15/Per/M.KUKM/IX/2015 tentang Usaha Simpan Pinjam Oleh Koperasi.

Rencana Induk Penelitian Universitas Muhammadiyah Jember 2020-2024.

Rencana Strategis (Renstra) Universitas Muhammadiyah Jember 2020-2024.

Undang-Undang Nomor 32 Tahun 2004 tentang Pemerintahan Daerah. 